\title{
THE ECONOMICS OF HAPPINESS IN ROBERT MICHELS \\ BETWEEN BENTHAMIAN UTILITARIANISM AND CIVIL ECONOMY
}

In Happiness And Contemporary Society : Conference Proceedings Volume (Lviv, March, 20-21, 2021). Lviv: SPOLOM, 2021. P. 199-204. https://doi.org/10.31108/7.2021.45

ISBN 978-966-919-697-2 
https://doi.org/10.31108/7.2021.45

\author{
MONTESI Cristina \\ Researcher and Aggregate Professor \\ Department of Economics, University of Perugia (Perugia, Italy)
}

\title{
THE ECONOMICS OF HAPPINESS IN ROBERT MICHELS BETWEEN BENTHAMIAN UTILITARIANISM AND CIVIL ECONOMY
}

The paper thematizes the problematic relationship between economy and happiness covered by economist Robert Michels (1876-1936) in his book "The Economics of Happiness" written in 1918. In this book Michels, as a true frontier scholar, provides, well in advance of the acquisitions of the modern "science of happiness", an interdisciplinary reading of the different determinants of happiness and of their interactions, courageously refuting the monistic and reductionist paradigm of neoclassical economy dominant in his epoch.

The hedonistic conception of happiness conceived by Michels echoes that formulated by Jeremy Bentham, but Michels, unlike the Utilitarians of the eighteenth and nineteenth centuries, gives it an unexpected twist, by postulating heretically that happiness is the ultimate goal of economy and that wealth is only a means to achieve it. In establishing the primacy of happiness as the main purpose of economic activity, Michels follows in the footsteps of Neapolitan and Milanese Civil Economists of Enlightenment with whom he had other theoretical points of consonance which the paper highlights. However Michels' conception of happiness differs from Civil Economists' notion because it is primarily based on individual pleasure and not on relational goods, because it is disconnected from those components of gratuitousness which are immanent to sincere relational goods, because it is detached from the search for Common Good.

Finally the paper illustrates the multidimensional and innovative public policies which Michels suggests for the achievement of happiness by invoking a wide range of integrated interventions to be carried out by the State and by the workers' unions.

Keywords: Happiness Economics, Benthamian Utilitarianism, Civil Economy

The book "The Economy of Happiness", published in 1918, contains the opening lecture on the subject of the relation between economy and happiness given by Robert Michels, on February 26, 1915, a few months after his call as full professor of Political Economy at the University of Basel. As academic Robert Michels (1876-1936) taught only economics in various Italian and foreign universities throughout his life, but he was actually a more versatile and eclectic scholar. The scientific success paradoxically smiled on him as sociologist of political parties in democracy (coming to find the famous "iron law of the oligarchy") rather than as a reformist and innovative economist who, precisely because of these characteristics, was always misunderstood by his colleagues for all his life (Montesi, 2020). Robert Michels, as a true frontier intellectual, investigated the issue of happiness in an interdisciplinary key, courageously rejecting the monistic and reductionist paradigm of the neoclassical economy dominant in his time and anticipating many of the achievements of the modern "science of happiness" such as the existence of various "treadmill effects" (positional, hedonic, satisfaction). 
Michels' conception of happiness is similar to that formulated by Jeremy Bentham (1748-1832), the father of Utilitarianism. According to Bentham, happiness coincides with utility, utility coincides with pleasure, pleasure coincides with Good (therefore it has a moral value). The analogy with Bentham can be deduced from the way in which Michels defines happiness:

"[...] a state of mind, in which man feels that the sum of sorrows which touched him at that particular moment is, in intensity, less than the sum of the relative pleasures" (Michels, 2017, pp.172-173). From this definition it is clear that for Michels happiness has a sensory, not logical, substratum; that happiness is the product of the pleasure/pain dialectic; that happiness is a short-term, not a long-term, state of well-being. Michels'approach to happiness is therefore hedonistic (based on individual pleasure, not worrying Michels, unlike Bentham, of extending it to the greatest number of people) and not based on the "good life" in the Aristotelian sense. According to Michels happiness is the ultimate goal of individual and collective life, as well as of economic activity:

"The most intense and deepest desire of man is to achieve happiness. The economy also tends to this purpose, to which it is subordinated as a medium ad finem" (Michels, 2017, p.25). Even "[...] workers' movement [is] a movement aimed, above all, at happiness" (Michels, 2017, p.27) and policy makers must also address economic policies towards happiness. Michels is well aware that wealth does not determine happiness, but happiness presupposes a certain abundance of goods.

Wealth is therefore only a means to happiness, it is not happiness itself. Economic activity contributes to people happiness in different ways: as an employer, as a creator of wealth or income. The aim of economic science is not to search for "the means to increase wealth" as hypothesized by Adam Smith, the father of British Political Economy, but to "increase the possibility for men to live happily"(Michels, 2017, p.25). According to Michels, some famous economists of the past are part of this conception of the economic science as a "science of happiness": Sismonde de Sismondi, some English socialists (utopian socialists: Robert Owen; Ricardian socialists: William Thompson; John Gray), some French socialists (Joseph Proudhon), the Italian Civil Economists ${ }^{2}$ of the eighteenth century. Among Civil Economists expressly mentioned by Michels there are some exponents of Milanese Enlightenment (Pietro Verri, Ludovico Muratori) and of Neapolitan Enlightenment (Giuseppe Palmieri, Antonio Genovesi, the father of Civil Economy $)^{3}$.

Michels identifies the following economic variables as factors that exert, among other elements, an influence on happiness: the wage of the worker which must be also referred to working conditions; the relative salary; the richness.

\footnotetext{
${ }^{2}$ Civil Economy is a current of economic thought that aims to rejoin the fracture, operated by the twentieth-century neoclassical economy, between economy and ethics, between market and community, between profit and sociality, between business and territory. Civil Economy has its historical roots in Franciscan, Benedictine and Teresian spirituality; in Civil Humanism of the first half of the fifteenth century, in Italian Enlightenment. Bruni and Zamagni (2007; 2017), Montesi $(2011 ; 2016)$.

3 The theme of happiness appears explicitly in the title of the volume by Giuseppe Palmieri (Reflections on public happiness, 1787), in the title of the book by Ludovico Muratori (On public happiness, 1749), in the title of the work by Pietro Verri (Discourse on happiness, 1763). Antonio Genovesi also deals with public happiness in his book Lessons of Civil Economy (1765).
} 
Salary arises from dependent work and wage labor is neither natural nor innate, but it is a cultural product, fruit of the evolution of human civilization. In fact, work is a function of social norms, moral norms, as well as of production techniques adopted in a specific time. Wage work is not typically source of happiness, but it is more often cause of unhappiness for many reasons. The first reason is that wage labor is not free, but arises from worker's need to work to support himself. The second reason is that wage labour is a "commodity" subject to exploitation by capitalists. The third reason is that wage work involves fatigue (both physical and psychological) due to a series of subjective or objective factors.

Among subjective factors which can cause labour pains, Michels includes the individual nature of the worker (ie being lazy by nature) and the tendency of individuals to be guided by the "law of the least means" which has a psychological foundation and which consists in "obtaining a maximum result with a minimum effort" (Michels, pp. 44-45).

Among the objective factors which cause labour pain, Michels includes all those working conditions that can cause occupational diseases or stress. Working conditions depend in turn on the quality and quantity of the work performed, on unsanitary or unsafe working environment, on a very strong division of labor which, together with the use of machines, reduces the immaterial satisfaction of work because work becomes alienated, repetitive and boring, on the intrinsic instability of capitalism.

Among the economic determinants of happiness there is the relative wage, or the level of wages compared with the income received, in the same time interval, by the social group taken as reference by workers (the capitalist class). So even if the material conditions of the worker can be objectively improved, the worker can suffer from a "misery of comparison" (Michels, 2017, p.162). Michels argues that: "Confrontation kills, of its nature, auroral happiness" (Michels, 2017, p.162). Michels anticipates the results of the later research of Richard Easterling (Easterling, 1974; 2001) and of Robert Frank (Frank, 1985) on the link between relative income and happiness (positional treadmill). This link is one of the explanations for the "paradox of happiness in economics" existing in economically advanced countries for which happiness does not increase in line with individual's income increases once a certain income threshold has been crossed.

Wealth, both inherited or produced and accumulated through self-employment, has ambivalent effects on happiness. The positive effects can be of an economic, social, psychological nature.

According to Michels positive economic effects are substantiated in the fact that an increase in wealth entails, after the satisfaction of basic needs, an increase in the consumption of "comfort goods", even if the increase in happiness related to it finds its physiological limit in the law of decreasing marginal utility. This negative effect on happiness due to habit in consuming especially "comfort goods" is called hedonic treadmill (Brickman and Campbell, 1971).

A further increase in wealth leads to a qualitative diversification of consumption which progressively moves from "comfort goods" to the consumption of rare and expensive luxury goods (status symbol goods). Once the "conspicuous" consumption of "positional goods" has also reached saturation, consumption induced by greater wealth can be sublimated according to Michels in the purchase of "collection goods" or can flow into patronage or philanthropy.

The positive social effects of wealth on happiness can be summed up in the fact that the rich man is surrounded, depending on the cultures in force in a country, by 
admiration, he is usually filled with honors and soon becomes an object of emulation. Often an increase in wealth opens the door to a descent into political or diplomatic field.

The positive psychological effects of an increase in wealth involve the possibility of "satisfying the desire for domination over others" and the possibility of having greater influence in the very sphere of business. All these positive (economic, social, psychological) effects on happiness induced by wealth can be counterbalanced, according to Michels, by negative effects, equally multidimensional, which consist in the fact that wealth often carries with it many fears: the fear of losing it (more accentuated among the "nouveaux riches"), the fear of social envy or of class hatred, the fear of always being surrounded by profiteers and swindlers. Furthermore, the rich, if idle, tends to spend ever greater sums to combat boredom, ending up "going to ruin at breakneck speed" (Michels, 2017, p.89). Michels, critically refuting the neoclassical homo oeconomicus paradigm, identifies other non-economic factors (psychological, personality, demographic, cultural, social, accidental) which are the basis of the "paradox of happiness in economics". Among these factors, the most important are the psychological (even irrational) mechanisms that come into play. According to Michels "[..] happiness is a category of psychological rather than economic origin" (Michels, 2017, p.193).

The aptitude to make social comparisons, as already illustrated in relation to the importance of relative and not absolute wages for happiness, is an unstoppable psychological process which can negatively affect one's happiness. Another dynamic determinant, always of a psychological nature, of happiness is the increase in aspirations. People value their happiness in reference to their aspirations that move upwards as soon as a material goal has been reached. So the more you get, the more you want. This negative effect on happiness due to increased aspirations is called satisfaction treadmill (Kahneman, 2000).

Among personality factors which affect happiness Michels includes optimism, self-confidence and the natural vivacity of the individual, which Michels calls turgor vitalis, which can amplify moments of happiness or unhappiness.

Among demographic factors Michels includes age as the elderly are happier than young people because they have become more affluent over time, they have fewer desires and different needs from those of young people (mainly health preservation).

Among cultural factors which affect happiness Michels includes religion. Believers react better to adversity by being able to trust in divine Providence. Even the value systems of people and of societies, in relativizing the importance of money which does not make happiness in itself, can, according to Michels, weaken the influence of economic variables on happiness.

According to Michels happiness also depends on social factors, on relational goods (on family ties, friends ties, love ties, other social ties, all united by the fact that they are personal, genuine and non-instrumental ties), as confirmed by subsequent research conducted, only starting from the 1970s, to explain the paradox of happiness in economics. In industrialized countries the effect of an increase in income on relational goods (and therefore on the happiness that depends on them) is negative when a critical income threshold is exceeded. The increase in income, beyond this threshold, implies in fact a deterioration of relational goods because, being time-consuming, they always need time investments which are made impossible by the higher rates of work to earn more. The final results is a reduction in happiness. However Michels does not attribute to relational goods the same importance in happiness that Civil Economists gave them. For Civil Economists happiness was not a transitory individual pleasure like in Michels' view, but was essentially inter-subjective in fact they spoke of "public happiness", where 
"public" means "relational"), happiness was linked to the achievement of Common Good, happiness could not leave out of consideration those components of gratuitousness which are immanent to authentic relational goods.

The belonging of individuals to some particular professional categories (intellectuals, scientists, artists) means that their "professional happiness" does not depend only on economic variables, but on social acknowledgment within the professional community.

In addition to economic, personality, demographic, social, cultural factors there are also accidental factors which can temporarily nullify the effect of all others on happiness: "A misfortune, moral or physical, which affects the individual or his family, can destroy in an instant all the best subjective and objective predispositions to happiness" (Michels, 2017, p.183). In English language the word "happiness" derives from the verb "to happen". Happiness is constitutively fragile because it is exposed to the "lottery of fate", although the psychological mechanisms of "adaptation" which come into play after an adverse shock can, depending on its severity, help people with returning to their original level of happiness.

Michels' lesson is also illuminating as regards the relationship between politics and happiness which is very delicate because on one hand we should avoid the risks of an "Ethical State" which, in an organicistic way, prescriptively dictates the lifestyle to follow as if happiness should be a "public duty" to be fulfilled by its citizens, and on the other hand we should avoid the Jeffersonian vision of happiness as an "individual right" which any State must not violate. Michels has, in a balanced way, theorized an active (but not excessively invasive) role of the State in the indirect pursuit of objective happiness of its citizens.

State policies for happiness are, according to Michels, the policies for the cultural growth of a country that provide workers with books to read or with film screenings to mitigate work alienation; the policies which affect labor market institutions (see Michels' proposal for a minimum wage); the policies that improve the quality of work by promoting the transition from labor (the activity that exploits worker causing him a loss of life) to work (a healthy, meaningful and morally good activity); the policies that make workplaces safer and healthier; the policies of demographic control which educate workers to procreate in a way consistent with family income; the policies which are adopted to "cure" those market failures which most affect people's happiness.

In this last category there are the policies which reduce macroeconomic instability such as policies against unemployment; the policies for the reduction of income inequalities through progressive taxation on income and the exemption of income taxes below a certain threshold; the policies which insure workers against life and market risks through welfare state assistance and through community welfare measures (the mutual funds of workers' leagues); the policies for the reduction of inequalities in capabilities with welfare state interventions to promote skills (investments in human capital aimed at increasing the level of education of the working class).

Michels' pioneering reflection on happiness is still valid and precious in the present because, unmasking some deceptions, Michels suggests people and policy makers some possible paths towards happiness, in the awareness that happiness is a balanced mix of enjoyment of rights (civil, social, political, cultural, environmental rights), of conditions of material well-being (the satisfaction of basic needs, the consumption of "creative or experiential goods" rather than of "positional goods" or "comfort goods"), of social well-being (the care of relational life in the name of 
generalized and symmetrical altruism), of spiritual well-being (including, in this sphere, also the "search for meaning" in our daily behavior, even in our economic actions).

\section{REFERENCES}

1. Brickman P.E, Campbell D.T. (1971), Hedonic relativism and planning the good society, in Appley M.A. (1971) (eds.), "Adaptation Level Theory", Academic Press, New York, pp. 287-302.

2. Bruni L., Zamagni S. (2007), Civil Economy: Efficiency, Equity, Public Happiness. Frontiers of Business Ethics, Peter Lang, Bern.

3. Bruni L., Zamagni S. (2017), Civil Economy: Another Idea of the Market, Columbia University Press.

4. Easterlin R.A. (1974), Does Economic Growth improves the Human Lot? Some Empirical Evidence, in Davis P.A., Reder M.W. (eds.), "Nation and Households in Economic Growth: Essays in Honour of Moses Abramowitz", Academic Press, New York-London, pp. 89-125.

5. Easterlin R.A. (2001), Income and Happiness: Toward a Unified Theory, in "The Economic Journal", n.111, pp. 465-484.

6. Frank R.H. (1985), Choosing the Right Pond: Human Behavior and the Quest for Status, Oxford University Press, New York.

7. Genovesi A. (2013), Lezioni di Economia Civile, Vita e Pensiero, Milano, 2013.

8. Kahneman D. (2000), Experienced utility and objective happiness: a moment-based approach, in Kahneman D., Tversky A. (2000) (eds.), "Choices, Values and Frames", Cambridge University Press and the Russell Sage Foundation, New York, pp. 673-692.

9. Michels R. (2017), L'economia della felicità, Oaks Editrice, Sesto San Giovanni, Milano.

10. Melasecche A., Montesi C., Terenziani P. (2010), Economie et bonheur: un binôme incontournable pour dépasser la crise, in Sterbova L., Martin C. (2010) (eds.), "La Crise Mondiale et les Perspectives de Reprise dans l'Union Europeenne", Edition de la Université de Prague, pp.216-228.

11. Montesi C. (2011), St.Benedict's Legacy: an European Lesson of "Civil Economy" about System's Competitiveness and Company's competitive Advantage, in Martin C. (2011) (eds.), "L'UE et Ses Rapports au Monde. Perte de Statut ou Emergence d'un Noveau Modele de Croissance Made in Europe? ", Université Pierre MendèsFrance de Grenoble Editions PGV, Grenoble, pp.610-628.

12. Montesi C. (2015), A Lesson of Civil Economy by Saint Teresa of Avila in crisis time, in Perez Cuenca I., Abradelo de Usera I., Cid Vazquez T. (2015) (ed.), "Santa Teresa de Jesus Maestra de Vida", Servicio de Publicaciones Universidad Catolica de Avila, Avila, pp.793-809.

13. Montesi C. (2016), Il Paradigma dell'economia civile. Radici storiche e nuovi orizzonti, Umbria Volontariato Edizioni, Terni.

14. Montesi C. (2020), La scommessa della felicità nel pensiero economico di Robert Michels, in Federici R. (2020) (eds.), "Robert Michels. Un intellettuale di frontier", Meltemi, Milano, pp.75-110. 